Article

\title{
A Comparative Study of Frequency Ratio, Shannon's Entropy and Analytic Hierarchy Process (AHP) Models for Landslide Susceptibility Assessment
}

\author{
Sandeep Panchal *(D) and Amit K. Shrivastava (D) \\ Department of Civil Engineering, Delhi Technological University, Main Bawana Road, Samaypur Badli, \\ Delhi 110042, India; aksrivastava@dce.ac.in \\ * Correspondence: 2290sandy@gmail.com; Tel.: +91-87-0863-1157
}

check for

updates

Citation: Panchal, S.; Shrivastava, A.K. A Comparative Study of Frequency Ratio, Shannon's Entropy and Analytic Hierarchy Process (AHP) Models for Landslide Susceptibility Assessment. ISPRS Int. J. Geo-Inf. 2021, 10, 603. https:// doi.org/10.3390/ijgi10090603

Academic Editors: Wolfgang Kainz and Peter Blišt'an

Received: 3 August 2021

Accepted: 9 September 2021

Published: 12 September 2021

Publisher's Note: MDPI stays neutral with regard to jurisdictional claims in published maps and institutional affiliations.

Copyright: (c) 2021 by the authors. Licensee MDPI, Basel, Switzerland. This article is an open access article distributed under the terms and conditions of the Creative Commons Attribution (CC BY) license (https:// creativecommons.org/licenses/by/ $4.0 /)$.

\begin{abstract}
Landslide susceptibility maps are very important tools in the planning and management of landslide prone areas. Qualitative and quantitative methods each have their own advantages and dis-advantages in landslide susceptibility mapping. The aim of this study is to compare three models, i.e., frequency ratio (FR), Shannon's entropy and analytic hierarchy process (AHP) by implementing them for the preparation of landslide susceptibility maps. Shimla, a district in Himachal Pradesh (H.P.), India was chosen for the study. A landslide inventory containing more than 1500 landslide events was prepared using previous literature, available historical data and a field survey. Out of the total number of landslide events, 30\% data was used for training and $70 \%$ data was used for testing purpose. The frequency ratio, Shannon's entropy and AHP models were implemented and three landslide susceptibility maps were prepared for the study area. The final landslide susceptibility maps were validated using a receiver operating characteristic (ROC) curve. The frequency ratio (FR) model yielded the highest accuracy, with 0.925 fitted ROC area, while the accuracy achieved by Shannon's entropy model was 0.883 . Analytic hierarchy process (AHP) yielded the lowest accuracy, with 0.732 fitted ROC area. The results of this study can be used by engineers and planners for better management and mitigation of landslides in the study area.
\end{abstract}

Keywords: landslide susceptibility mapping; AHP; Shannon's entropy; frequency ratio; landslide inventory

\section{Introduction}

Hilly regions are frequently affected by landslide disasters. Landslides are responsible for huge loss of life and damage to infrastructure [1,2]. A landslide is the result of movement of a slope under the effect of gravity, but the movement can be triggered by the factors such as rainfall, earthquakes, erosion, etc. $[3,4]$. The accurate prediction of landslides can help in the planning and management of landslide hazards, and can ultimately be used for the reduction of risk [5]. Landslide susceptibility maps help in the identification of landslide prone areas. Landslide susceptibility maps can be very efficient tools for planners and risk managers [5]. The occurrence of landslides is a complex phenomenon which depends upon various factors. Geological factors, drainage characteristics, land-use of the region, construction activities, etc., can all be responsible for the occurrence of landslides [6]. Anthropogenic activities and the development of infrastructure in landslide prone areas can disturb natural slopes, resulting in massive disaster $[7,8]$.

The study area selected in this study is the Shimla district in Himachal Pradesh (H.P.), India. The study area is developing at a very rapid rate. Anthropogenic activities have been increasing in the study area, resulting in the instability of natural slopes. Landslide occurrence is very frequent in the study area due to rugged topographic and the typical climatic conditions in the region. Therefore, there is a need for the preparation of a landslide susceptibility map for the region which can be used by planners and engineers. 
In different regions of the world, landslide susceptibility mapping has been undertaken by various researchers, using geographic information systems (GIS) and remote sensing $[2,4,6,9-14]$. Qualitative and quantitative approaches are both widely used. Qualitative techniques consider expert opinion, while quantitative approaches establish a mathematical relationship between causative factors and the occurrence of landslide [2,5,13,15-17]. Landslide inventory-based methods utilize a direct approach in which susceptibility maps are prepared by considering the geomorphological characteristics of the region. Ranking and weightage are introduced to improve direct susceptibility mapping, through analytic hierarchy processes (AHP), analytic network processes (ANP), fuzzy logic, etc. [15-18]. These methods can be categorized as semi-qualitative methods. Quantitative methods such as the bivariate method [19-21], multi-variate method [22-24], weight of evidence [25,26], etc., are widely used with the development of GIS techniques. GIS platforms help in the calculation and visualization of the cumulative effects of causative factors on landslides. Qualitative techniques are based on the subjective judgment of experts, while the output in quantitative techniques depends on the availability of historical landslide data [27].

Landslide susceptibility mapping has not been undertaken for the study area until now. There is a need for the preparation of an accurate landslide susceptibility map for the region. In this study, we used three techniques for landslide susceptibility mapping, i.e., frequency ratio (FR), Shannon's entropy model and analytic hierarchy process (AHP). Shannon's entropy model is an improvement over the frequency ratio model and is rarely used in the Indian continent for landslide susceptibility mapping. The results of this study can help in the delineation of landslide prone regions in the study area. Construction planners, environmental engineers and risk managers can use the results of this study for the planning and mitigation of landslide hazards in the study area.

\section{Study Area}

Figure 1a shows the methodology adopted in this study. In the first step, the study area is selected. Shimla is the capital of Himachal Pradesh (H.P.) province in India. The region lies between longitudes $77^{\circ} 0^{\prime} \mathrm{E}$ and $78^{\circ} 19^{\prime}$ and latitudes $30^{\circ} 45^{\prime}$ and $31^{\circ} 44^{\prime}$. The elevation of the region varies from $300 \mathrm{~m}$ to $6000 \mathrm{~m}$ and shows variation in the vegetation [28,29]. The study area lies in the Kashmir and Western Himalayas seismic region. Shimla district lies in a high damage risk zone in the case of seismic activity (MSK VIII) [28,29]. Major earthquakes that have occurred in Himachal Pradesh (H.P.) are the Kangra earthquake $1905(M=8)$, the Chamba earthquake $1945(M=6.5)$, the Kinnaur earthquake $(M=6.8)$, etc. The study area is predominantly covered by rock from the Jutogh, Shali, Simla and Rampur groups. The study area consists of lithological units of shale, siltstones, quartzite, dolomites, phyllite, schist, conglomerate, etc. The region is predominantly covered by the Proterozoic age group, Plaeo-proterozoic age group and Neo-proterozoic age group. The study area is mainly forest and cultivated land. Some of the study area in upper Shivaliks consists of hill tops with snow. The temperature varies from $4{ }^{\circ} \mathrm{C}$ to $31^{\circ} \mathrm{C}[28,29]$. Therefore, the region is cool in winter and moderately warm in summer. Figure $1 \mathrm{~b}$ shows the study area and landslide inventory.

\subsection{Landslide Inventory}

A landslide inventory plays an important role in the mathematical modelling and validation of the final output [13]. Landslide inventories consist of information regarding the location of landslides, area of landslides, activity and date of landslides, etc. [30]. A landslide inventory can be simple to complex, depending upon the requirement of study. A landslide inventory is prepared from previous literature, Google Earth and field visits. The field visits cannot be undertaken frequently due to restricted movement in the current COVID-19 pandemic. The landslide inventory consists of more than 1500 landslides in the study area. The landslides are represented by polygons. Figure 1 shows the landslide inventory. 


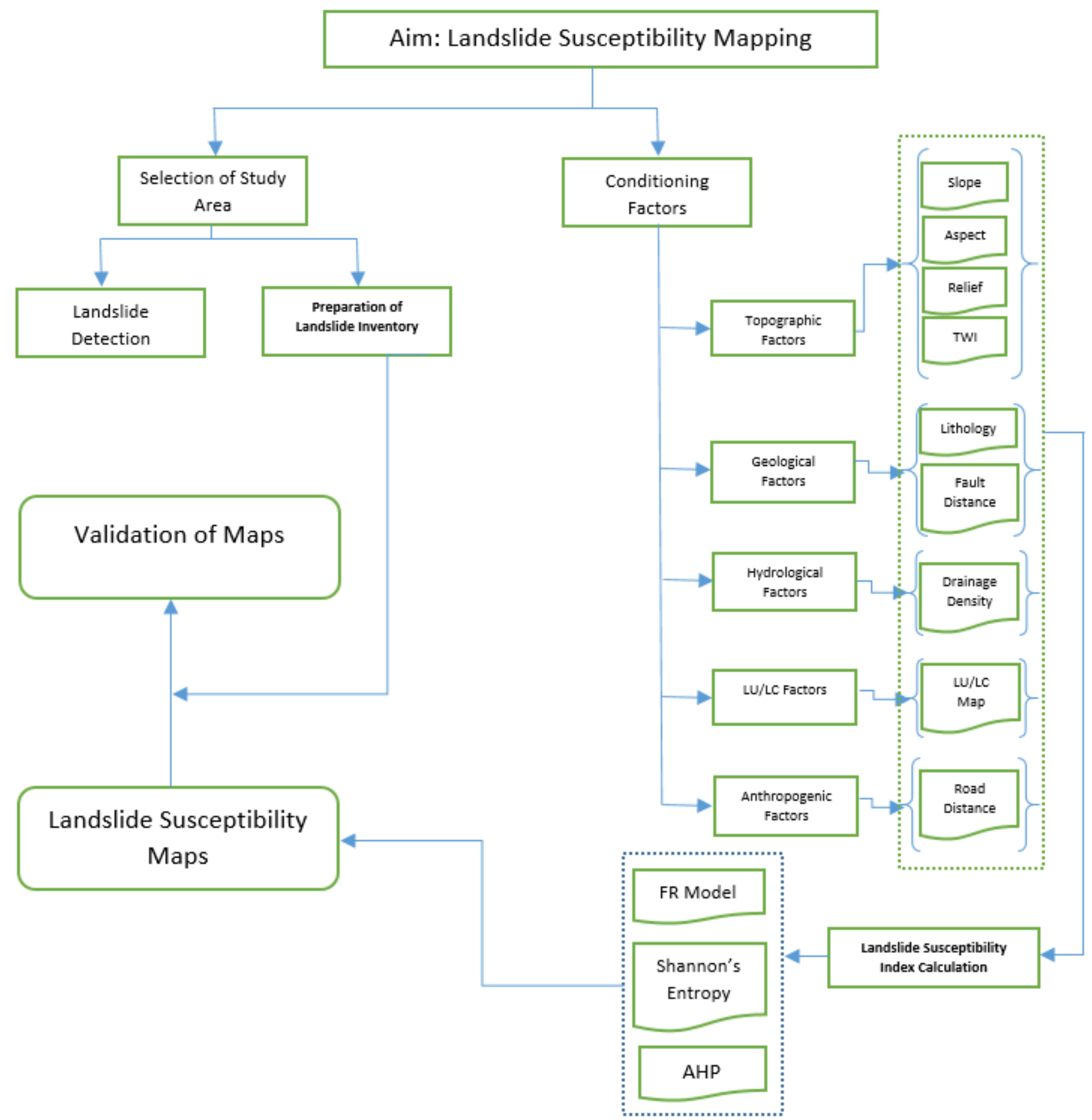

(a)

Figure 1. Cont. 


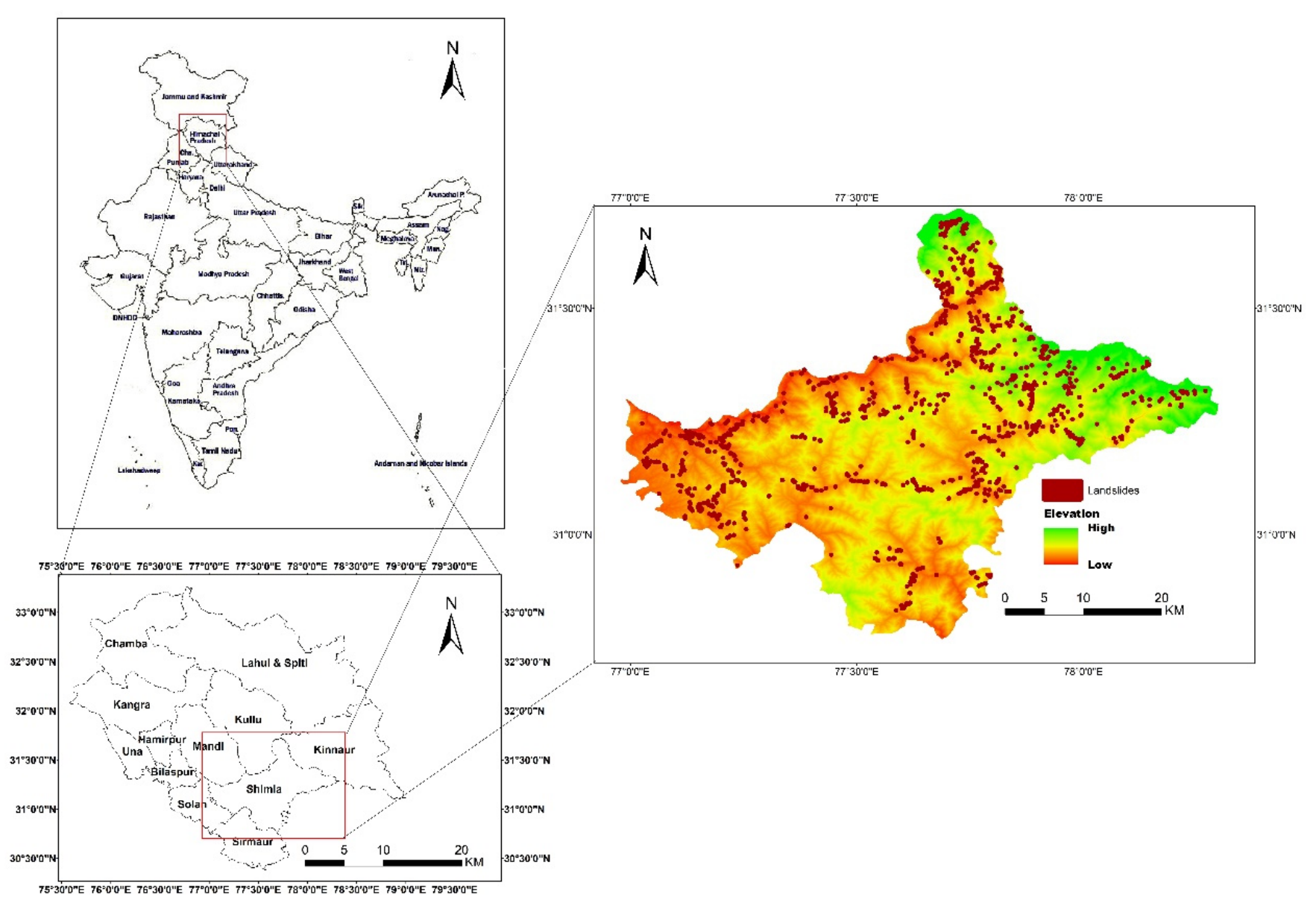

(b)

Figure 1. (a) Flow chart of methodology, (b) Study area and landslide inventory.

\subsection{Landslide Conditioning Factors}

Understanding the causative factors of landslides for the preparation of landslide susceptibility maps is very important. The data for the preparation of thematic layers of causative factors were obtained from different sources. An ASTER digital elevation model (DEM) was obtained from the USGS website. The resolution of the DEM used in this study is 1 arc second, which is approximately equal to $30 \times 30 \mathrm{~m}$. The average route mean square error (RMSE) in the measurement of elevation is $\pm 13.31 \mathrm{~m}$. In terms of absolute positioning, the ASTER DEM models have a tendency for displacement by $5.3 \mathrm{~m}$ in our study. Landsat 8 data was used for the preparation of a land-use map for the study area. The resolution for Landsat bands 1-7 is $30 \times 30 \mathrm{~m}$. Hydrogeological and topographical maps were used for the digitization of faults, lithology and the road network. The land cover of the study area was obtained from Landsat 8 data.

Selection of condition factors depends on the availability of data, ease of use and the results of a literature survey. In many studies, DEM based factors are considered to be major causative factors, but in recent studies, land use, drainage networks and faults or lineaments are also considered to be responsible for landslide occurrence. The factors considered in this study are explained as follows. The relative importance of the causative factors can be found using Shannon's entropy and the AHP model. 


\subsubsection{Slope Gradient}

Slope gradient may be defined as the rate of change in elevation with respect to horizontal surface. When the shear stresses in a downward direction exceed the shear strength of soil or rock mass, the failure of slopes occur. Therefore, the slope angle directly affects the stability of slope [31]. The slope of the study area was extracted from a digital elevation model (DEM) of the study area. The study area is comprised predominantly of steep slopes greater than $60^{\circ}$. As the slope angle increases, the possibility of slope failure increases. Figure 2a shows slope gradient of the study area.
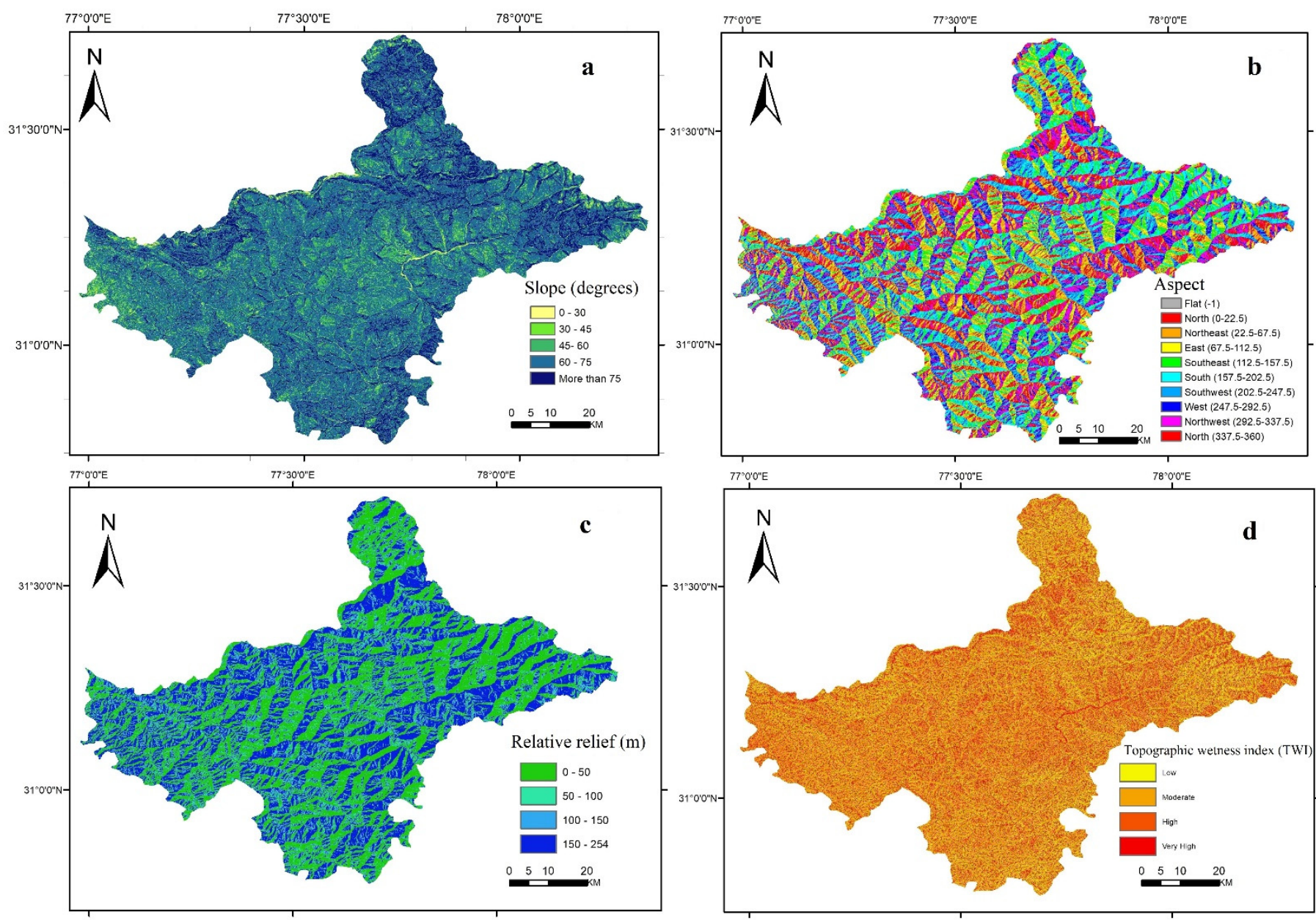

Figure 2. Causative factors: (a) Slope gradient (b) Slope aspect (c) Relative relief (d) Topographic wetness index.

\subsubsection{Slope Aspect}

Slope aspect gives the direction of maximum slope with respect to magnetic north. Slope aspect affects erosion, evapotranspiration, desertification, solar heating and soil moisture [5]. Slope aspect indirectly shows the impact of water on the mass. Figure $2 b$ shows the slope aspect of the study area.

\subsubsection{Relative Relief}

Relative relief shows the change in elevation. The change in elevation indicates variation in vegetation type and topographical characteristics of the region [13]. Vegetation roots hold the rock and soil mass together and make it more stable. The relative relief varies from 0 to $254 \mathrm{~m}$ in the present study. Figure 2c shows the relative relief of the region. 


\subsubsection{Topographic Wetness Index (TWI)}

The topographic wetness index (TWI) is the tendency of terrain to accumulate water. It indicates variation in soil moisture [32]. Figure $2 \mathrm{~d}$ shows the TWI of the region. If SCA is specific catchment area and $\varphi$ is the angle of slope, TWI is given by the following formula:

$$
T W I=\ln \left(\frac{S C A}{\tan \varphi}\right)
$$

\subsubsection{Lithology}

Lithology is an important causative factor of landslides. Variation in rock characteristics and age prominently affect landslide events [33]. Detailed information about the lithological and geological character of the region is given in Table 1. Figure 3a shows the lithology of the region.

Table 1. Lithology of the study area.

\begin{tabular}{|c|c|c|c|}
\hline Age & Group Name & Geological Formation & Lithology \\
\hline Mesoproterozoic & Shali & Tatapani & $\begin{array}{c}\text { Pink and grey dolomite, } \\
\text { phyllite, shale }\end{array}$ \\
\hline Neoproterozoic & Shali & Sorgharwari & $\begin{array}{c}\text { Pink and grey limestone, } \\
\text { sporadic shale }\end{array}$ \\
\hline Palaeocene-Eocene & $\begin{array}{c}\text { Sirmur } \\
\text { Dharmshala Group }\end{array}$ & Subathu & $\begin{array}{c}\text { Green carbonaceous } \\
\text { shale, } \\
\text { limestone, quartzite }\end{array}$ \\
\hline Palaeoproterozoic & Kulu & Khokhan & Schist and quartzite \\
\hline Palaeozoic & Not available & Not available & $\begin{array}{l}\text { Medium to coarse } \\
\text { biotite granite }\end{array}$ \\
\hline $\begin{array}{l}\text { Proterozoic } \\
\text { (Undiff) }\end{array}$ & Jutogh & Manal, chor, pabar & $\begin{array}{l}\text { White grey quartzite, } \\
\text { schist, carbonaceous } \\
\text { dolomite, granite, gneiss }\end{array}$ \\
\hline
\end{tabular}

\subsubsection{Drainage Density}

The drainage characteristics of the region significantly affect the occurrence of landslides. River water erodes the soil at the toe of the slope and weakens the base, which may result in slope failure [33,34]. Drainage density is divided into four categories for the study area. Higher drainage density increases the risk of landslides. Figure $3 \mathrm{~b}$ shows the drainage density of study area.

\subsubsection{Distance from Roads}

Road construction disturbs the natural slopes along highway corridors. Road construction activities involve significant cutting and filling activities. The bottom section of a slope is weakened by the soil and rock cutting activities during highway construction [35]. Vehicular vibrations, excessive excavations and disturbed natural slopes all induce instability and increase the risk of landslide occurrence. Slopes existing near roads are more prone to experience landslides [13,35]. A detailed analysis of slope stability during the planning of construction of projects can reduce the risk of landslide occurrence. Distance from roads indirectly represents the effects of human interference on natural slopes. If proper slope protection is provided and the slopes along highways are planned properly, the risk of landslides along highways can be reduced. Figure $3 \mathrm{c}$ shows the distance from roads. 

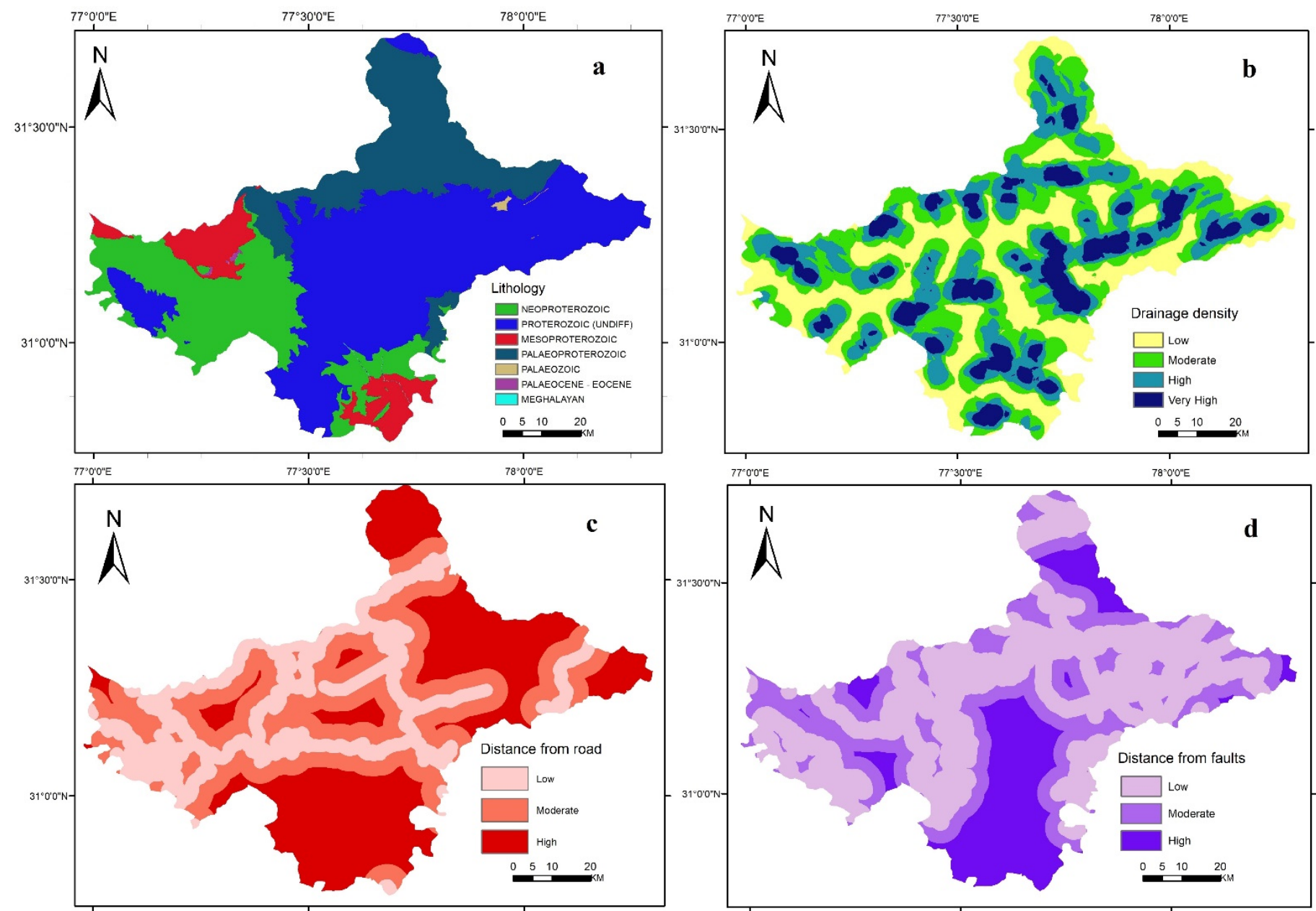

Figure 3. Causative factors: (a) Lithology (b) Drainage density (c) Distance from road (d) Distance from faults.

\subsubsection{Distance from Faults}

Cracks, faults, fissures and lineament can increase pore pressure in the rock and soil mass, and can induce instability in slopes [36,37]. In this study, faults were digitized from NRSA data. Proximity to faults is considered a causative factor in this study, and Euclidean distance from faults was calculated in ArcGIS. Figure 3d shows distance from faults.

\subsubsection{Land Cover}

Land cover is an important factor that affects the occurrence of landslides. Vegetation area, forest area, barren land, etc. are shown in a land cover map, and may affect the occurrence of landslides due to their diverse characteristics. A land cover map was extracted from Landsat 8 imagery. The land use was classified using a supervised learning technique of image classification in ArcGIS. The study area is predominantly covered with the cropland and forests. In the upper elevations, there are glaciers and snow covered hill tops as well. Figure 4 shows the land cover map of the region. 


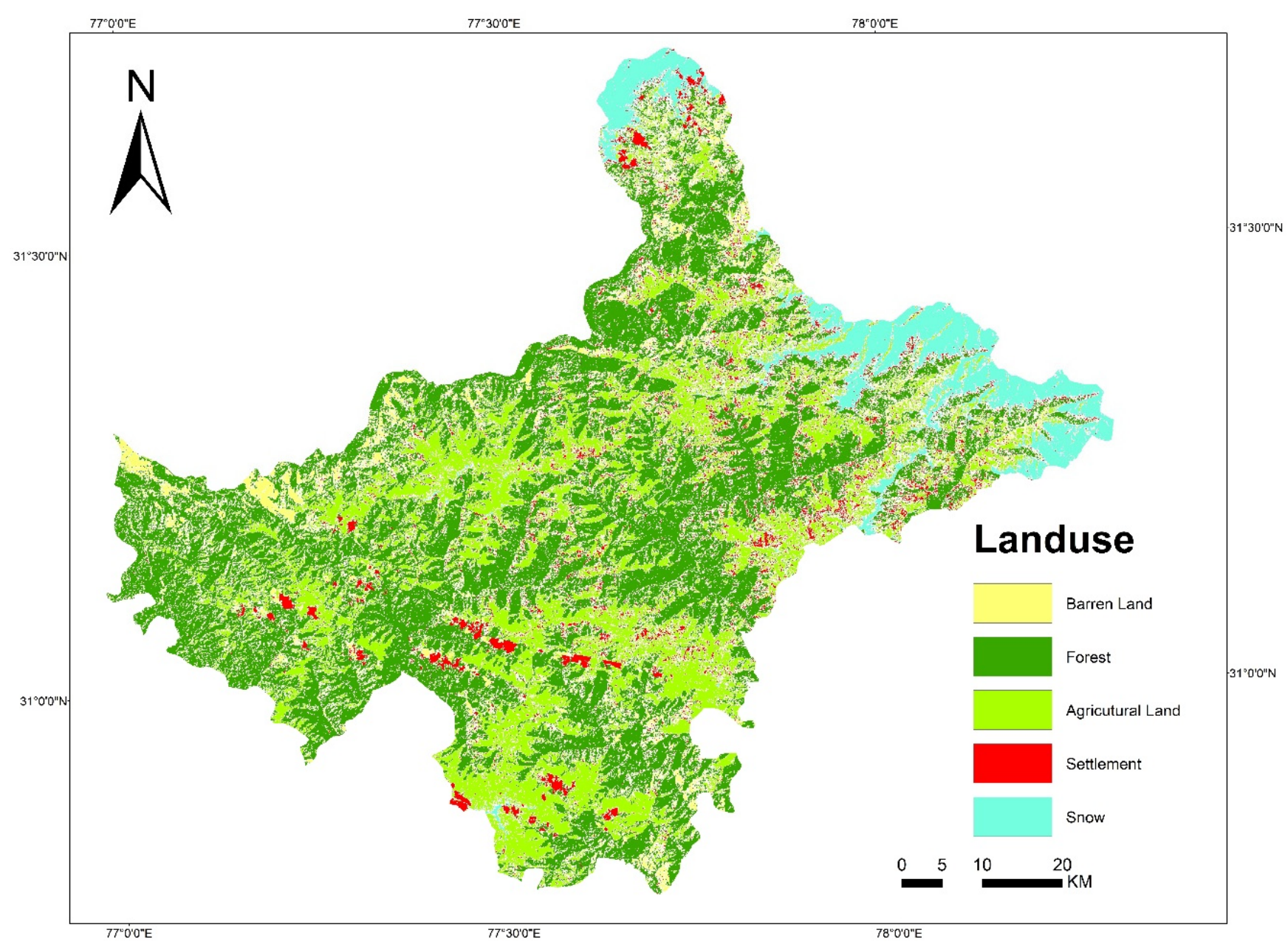

Figure 4. Land-use/land cover map.

\section{Modelling Approach}

\subsection{Frequency Ratio}

Frequency ratio models are based upon the relationship between the occurrence of landslide events and the causative factors [38,39]. A relationship between the landslide inventory and causative factors can be established in a GIS environment. A landslide will occur under the same conditions as past landslides [5]. The frequency ratio is the ratio between the percent areas where landslides have occurred in a class to the percent area of the influencing class relative to the whole study area as shown in the following formula [40].

$$
F r=\frac{\left(\frac{M i}{M}\right)}{\left(\frac{N i}{N}\right)}
$$

where $\mathrm{Mi}=$ Number of pixels containing landslides in a class; $\mathrm{M}=$ Total number of pixels in a class; $\mathrm{Ni}=$ Total number of pixels containing landslides; $\mathrm{N}=$ Total number of pixels in the study area.

The landslide susceptibility index is calculated by summing up the Fr for each sub-factors:

$$
\begin{aligned}
& \text { Landslide Susceptibility Index (LSI) } \\
& =F r_{1}+F r_{2}+F r_{3}+F r_{4}+\ldots \ldots \ldots \ldots \ldots \ldots \ldots+F r_{n}
\end{aligned}
$$

where Fr is frequency ratio and $\mathrm{n}$ is number of causative factors. Table 2 shows the frequency ratio (FR) calculation. 
Table 2. Frequency ratio and Shannon's entropy weightage.

\begin{tabular}{|c|c|c|c|c|c|c|c|c|c|c|}
\hline $\begin{array}{l}\text { Conditioning } \\
\text { Factor }\end{array}$ & Classes & $\begin{array}{l}\text { No. of Pixels } \\
\text { in Class }\end{array}$ & $\begin{array}{l}\text { Percentage } \\
\text { in Class (a) }\end{array}$ & $\begin{array}{l}\text { No. of Landslide } \\
\text { Pixel in Class }\end{array}$ & $\begin{array}{l}\text { Percentage of } \\
\text { Landslide } \\
\text { Pixel (b) }\end{array}$ & $\begin{array}{c}\text { FR } \\
(\mathrm{b} / \mathrm{a})\end{array}$ & $\mathbf{P i j}$ & Eij & $\mathrm{Hij}=1-\mathbf{E i j}$ & $\mathbf{W j}$ \\
\hline \multicolumn{11}{|l|}{ Slope } \\
\hline & $<30$ & $107,718.000$ & 1.710 & 13.000 & 0.800 & 0.468 & 0.115 & -0.108 & \multirow{6}{*}{0.442} & \multirow{6}{*}{0.120} \\
\hline & $30-45$ & $246,772.000$ & 3.900 & 13.000 & 0.800 & 0.205 & 0.050 & -0.065 & & \\
\hline & $45-60$ & $1,001,205.000$ & 15.910 & 91.000 & 5.950 & 0.374 & 0.092 & -0.095 & & \\
\hline & $60-75$ & $3,779,957.000$ & 60.050 & 803.000 & 52.510 & 0.874 & 0.214 & -0.143 & & \\
\hline & More than 75 & $1,158,974.000$ & 18.410 & 609.000 & 39.830 & 2.163 & 0.530 & -0.146 & & \\
\hline & & $6,294,626.000$ & & 1529.000 & & 4.085 & & -0.558 & & \\
\hline \multicolumn{11}{|l|}{ Aspect } \\
\hline & Flat & 105.000 & 0.002 & 0.000 & 0.000 & 0.000 & 0.000 & 0.000 & \multirow{10}{*}{0.124} & \multirow{10}{*}{0.033} \\
\hline & North & $916,307.000$ & 14.560 & 210.000 & 13.730 & 0.943 & 0.116 & -0.108 & & \\
\hline & Northeast & $792,179.000$ & 12.590 & 156.000 & 10.200 & 0.810 & 0.100 & -0.100 & & \\
\hline & East & $627,294.000$ & 9.970 & 255.000 & 16.680 & 1.673 & 0.206 & -0.141 & & \\
\hline & South East & $804,073.000$ & 12.770 & 290.000 & 18.970 & 1.486 & 0.183 & -0.135 & & \\
\hline & South & $900,237.000$ & 14.310 & 230.000 & 15.040 & 1.051 & 0.129 & -0.115 & & \\
\hline & South West & $809,177.000$ & 12.860 & 135.000 & 8.830 & 0.687 & 0.084 & -0.091 & & \\
\hline & West & $643,538.000$ & 10.220 & 150.000 & 9.810 & 0.960 & 0.118 & -0.109 & & \\
\hline & North West & $801,716.000$ & 12.730 & 103.000 & 6.740 & 0.529 & 0.065 & -0.077 & & \\
\hline & & $6,294,626.000$ & & 1529.000 & 100.000 & 8.139 & & -0.876 & & \\
\hline \multicolumn{11}{|l|}{$\begin{array}{l}\text { Relative } \\
\text { relief }\end{array}$} \\
\hline & $0-50$ & $2,612,642.000$ & 41.660 & 804.000 & 52.580 & 1.262 & 0.323 & -0.159 & \multirow{5}{*}{0.408} & \multirow{5}{*}{0.110} \\
\hline & $50-100$ & $691,263.000$ & 11.023 & 145.000 & 9.480 & 0.860 & 0.220 & -0.145 & & \\
\hline & $100-150$ & $710,948.000$ & 11.337 & 186.000 & 12.160 & 1.073 & 0.274 & -0.154 & & \\
\hline & More than 150 & $2,256,417.000$ & 35.980 & 394.000 & 25.770 & 0.716 & 0.183 & -0.135 & & \\
\hline & & $6,271,270.000$ & & 1529.000 & & 3.911 & & -0.592 & & \\
\hline \multicolumn{11}{|l|}{ TWI } \\
\hline & Low & $2,810,725.000$ & 44.650 & 712.000 & 46.560 & 1.043 & 0.340 & -0.159 & \multirow{5}{*}{0.500} & \multirow{5}{*}{0.135} \\
\hline & Moderate & $2,473,126.000$ & 39.290 & 596.000 & 38.980 & 0.992 & 0.323 & -0.159 & & \\
\hline & High & $855,581.000$ & 13.590 & 207.000 & 13.540 & 0.996 & 0.325 & -0.159 & & \\
\hline & Very High & $155,194.000$ & 24.650 & 14.000 & 0.910 & 0.037 & 0.012 & -0.023 & & \\
\hline & & $6,294,626.000$ & & 1529.000 & & 3.068 & & -0.500 & & \\
\hline \multicolumn{11}{|l|}{ Lithology } \\
\hline & Neoproterozoic & $1,364,515.000$ & 21.680 & 415.000 & 27.150 & 1.252 & 0.408 & -0.159 & \multirow{8}{*}{0.401} & \multirow{8}{*}{0.109} \\
\hline & $\begin{array}{l}\text { Proterozoic } \\
\text { (Undiff) }\end{array}$ & $3,023,399.000$ & 48.030 & 415.000 & 27.140 & 0.565 & 0.184 & -0.135 & & \\
\hline & Mesoproterozoic & $502,058.000$ & 7.970 & 143.000 & 9.350 & 1.173 & 0.382 & -0.160 & & \\
\hline & Plaeoproterozoic & $1,384,339.000$ & 22.000 & 556.000 & 36.360 & 1.653 & 0.539 & -0.145 & & \\
\hline & Palaeozoic & $10,282.000$ & 0.160 & 0.000 & 0.000 & 0.000 & 0.000 & & & \\
\hline & $\begin{array}{l}\text { Palaleocene- } \\
\text { eocene }\end{array}$ & 7564.000 & 0.130 & 0.000 & 0.000 & 0.000 & 0.000 & & & \\
\hline & Meghalayan & 2469.000 & 0.030 & 0.000 & 0.000 & 0.000 & 0.000 & & & \\
\hline & & $6,294,626.000$ & & 1529.000 & & 4.643 & & -0.599 & & \\
\hline \multicolumn{11}{|l|}{$\begin{array}{c}\text { Drainage } \\
\text { density }\end{array}$} \\
\hline & $0-15$ & $2,309,122.000$ & 36.680 & 320.000 & 20.930 & 0.571 & 0.186 & -0.136 & \multirow{5}{*}{0.403} & \multirow{5}{*}{0.109} \\
\hline & $15-30$ & $2,194,591.000$ & 34.860 & 628.000 & 41.070 & 1.178 & 0.384 & -0.160 & & \\
\hline & $30-45$ & $1,441,690.000$ & 22.900 & 438.000 & 28.640 & 1.251 & 0.408 & -0.159 & & \\
\hline & $\begin{array}{l}\text { More than } 45 \\
\quad \text { (up to } 66 \text { ) }\end{array}$ & $349,223.000$ & 5.550 & 143.000 & 9.350 & 1.685 & 0.549 & -0.143 & & \\
\hline & & $6,294,626.000$ & & 1529.000 & & & & -0.597 & & \\
\hline
\end{tabular}


Table 2. Cont.

\begin{tabular}{|c|c|c|c|c|c|c|c|c|c|c|}
\hline $\begin{array}{l}\text { Conditioning } \\
\text { Factor }\end{array}$ & Classes & $\begin{array}{l}\text { No. of Pixels } \\
\text { in Class }\end{array}$ & $\begin{array}{l}\text { Percentage } \\
\text { in Class (a) }\end{array}$ & $\begin{array}{l}\text { No. of Landslide } \\
\text { Pixel in Class }\end{array}$ & $\begin{array}{l}\text { Percentage of } \\
\text { Landslide } \\
\text { Pixel (b) }\end{array}$ & $\begin{array}{l}\text { FR } \\
(\mathbf{b} / \mathbf{a})\end{array}$ & Pij & Eij & $\mathrm{Hij}=1-\mathrm{Eij}$ & $\mathbf{W j}$ \\
\hline \multicolumn{11}{|l|}{$\begin{array}{l}\text { Distance } \\
\text { from road }\end{array}$} \\
\hline & $0-1.5 \mathrm{KM}$ & $1,743,800.000$ & 27.700 & 531.000 & 34.720 & 1.253 & 0.409 & -0.159 & \multirow{4}{*}{0.547} & \multirow{4}{*}{0.148} \\
\hline & $1.5-5.5 \mathrm{~km}$ & $2,114,630.000$ & 33.590 & 286.000 & 18.700 & 0.557 & 0.181 & -0.134 & & \\
\hline & More than 5.5 & $2,436,196.000$ & 38.700 & 712.000 & 46.560 & 1.203 & 0.392 & -0.159 & & \\
\hline & & $6,294,626.000$ & & 1529.000 & & & & -0.453 & & \\
\hline \multicolumn{11}{|l|}{$\begin{array}{l}\text { Distance } \\
\text { from faults }\end{array}$} \\
\hline & $0-1.5 \mathrm{KM}$ & $2,790,363.000$ & 44.330 & 674.000 & 44.080 & 0.994 & 0.324 & -0.159 & \multirow{4}{*}{0.587} & \multirow{4}{*}{0.159} \\
\hline & $1.5 \mathrm{~km}-3.0 \mathrm{~km}$ & $1,295,638.000$ & 58.660 & 298.000 & 19.490 & 0.332 & 0.108 & -0.105 & & \\
\hline & more than $3 \mathrm{~km}$ & $2,208,625.000$ & 35.090 & 557.000 & 26.420 & 0.753 & 0.245 & -0.150 & & \\
\hline & & $6,294,626.000$ & & 1529.000 & & & & -0.413 & & \\
\hline \multicolumn{11}{|c|}{ Landuse/landcover } \\
\hline & Snow & $440,046.000$ & 6.990 & 220.000 & 14.390 & 2.059 & 0.671 & -0.116 & \multirow{5}{*}{0.287} & \multirow{5}{*}{0.078} \\
\hline & Settlement & $604,702.000$ & 9.610 & 104.000 & 6.800 & 0.708 & 0.231 & -0.147 & & \\
\hline & $\begin{array}{l}\text { Agricultural } \\
\text { Land }\end{array}$ & $1,800,554.000$ & 28.600 & 246.000 & 16.080 & 0.562 & 0.183 & -0.135 & & \\
\hline & Forest & $3,148,252.000$ & 50.010 & 855.000 & 55.910 & 1.118 & 0.364 & -0.160 & & \\
\hline & Barren Land & $301,072.000$ & 4.790 & 104.000 & 6.800 & 1.420 & 0.463 & -0.155 & & \\
\hline & & $6,294,626.000$ & & 1529.000 & & & & -0.713 & 3.700 & \\
\hline
\end{tabular}

\subsubsection{Shannon's Entropy}

Shannon's entropy model is an improvement on the frequency ratio model. The frequency ratio model only considers the weightage of sub-factors, and does not consider the weightage of causative factors. Shannon's entropy measures the uncertainty or instability of a system [41]. With landslide susceptibility mapping, it measures the influence of causative factors on the occurrence of landslides [42-45]. Weightage of causative factors is calculated using the following procedure:

$$
\begin{aligned}
P_{i j} & =F R / \sum_{i=1}^{m} F R \\
\sum_{i=1}^{m} E_{i j} & =\sum_{i=1}^{m}\left(P_{i j}\right) \times\left(\ln P_{i j}\right) \\
H_{i j} & =1+\sum_{i=1}^{m} E_{i j} \\
W_{j} & =H_{i j} / \sum_{i=1}^{n} H_{i j}
\end{aligned}
$$

where Pij is the probability density and FR is the frequency ratio of sub-factors. Wj is the weightage of causative factors obtained from Shannon's entropy technique. These values can then be used for assigning weight to causative factors, while frequency ratio values are used for sub-factors. Table 2 shows Shannon's entropy weightage of causative factors.

\subsubsection{Analytic Hierarchy Process (AHP)}

Analytic hierarchy process (AHP) is a decision-making tool which helps to solve complex problems with simple criteria. AHP is based upon three principles i.e., decomposition of the problem, comparative judgment, and synthesis of relative importance or rankings [43]. In AHP, the problem is broken down into hierarchical criteria. These criteria are compared to each other. This process of relative comparison is called pair-wise com- 
parison. The eigen vector method is used to calculate the rankings and the consistency of the solution is then also checked by calculating the consistency ratio [43]. The consistency of the weights for relative importance assigned during the pairwise comparison can be checked for consistency using the equation given below.

$$
\text { Consistency Ratio }(C R)=\frac{C I}{R I}
$$

where, $\mathrm{CI}$ is consistency index while RI is randomness index.

$\mathrm{CI}$ is calculated as follows:

$$
\text { Consistency Index }(C I)=\frac{\lambda m a x-n}{n-1}
$$

where, $\lambda \max =$ Major eigen value and $\mathrm{n}=$ order of matrix.

Randomness index values are given by Saaty, which is dependent on the value of $n$. $\mathrm{RI}$ is the result of extensive experimentation on large dataset samples. If the $\mathrm{CR}$ values are less than $10 \%$, the pairwise comparison is considered consistent. If the CR value is more than $10 \%$, the solution is considered inconsistent and weights are reassigned in a pairwise comparison matrix. Tables 3 and 4 show the relative comparison matrix of AHP for causative factors and sub-factors.

\begin{tabular}{|c|c|c|c|c|c|c|c|c|c|c|}
\hline Causative Factors & 1 & 2 & 3 & 4 & 5 & 6 & 7 & 8 & 9 & Weightage \\
\hline Slope & 1 & & & & & & & & & 0.105 \\
\hline Aspect & 0.14 & 1 & & & & & & & & 0.016 \\
\hline Relative relief & 0.33 & 4 & 1 & & & & & & & 0.036 \\
\hline TWI & 2 & 5 & 3 & 1 & & & & & & 0.081 \\
\hline Lithology & 0.33 & 6 & 3 & 3 & 1 & & & & & 0.096 \\
\hline Drainage density & 3 & 7 & 5 & 3 & 3 & 1 & & & & 0.205 \\
\hline Distance from road & 2 & 9 & 7 & 5 & 3 & 3 & 1 & & & 0.28 \\
\hline Distance from faults & 3 & 8 & 6 & 4 & 2 & 0.33 & 0.33 & 1 & & 0.161 \\
\hline Landuse & 0.14 & 2 & 0.33 & 0.14 & 0.14 & 0.14 & 0.14 & 0.17 & 1 & 0.02 \\
\hline \multicolumn{11}{|c|}{$\mathrm{CR}=0.09$} \\
\hline
\end{tabular}

Table 3. AHP weightage for causative factors.

Table 4. Analytic hierarchy process (AHP) weightage and relative importance of sub-factors.

\begin{tabular}{cccccccccccc}
\hline $\begin{array}{c}\text { Conditioning } \\
\text { Factor }\end{array}$ & Classes & $\mathbf{1}$ & $\mathbf{2}$ & $\mathbf{3}$ & $\mathbf{4}$ & $\mathbf{5}$ & $\mathbf{6}$ & $\mathbf{7}$ & $\mathbf{8}$ & $\mathbf{9}$ & $\begin{array}{c}\text { Weightage } \\
\text { (Wi) }\end{array}$ \\
\hline Slope & & & & & & & & & & & 0.04 \\
& $>30$ & 1 & & & & & & & & & 0.054 \\
& $30-45$ & 2 & 1 & & & & & & & & 0.102 \\
& $45-60$ & 3 & 3 & 1 & & & & & & & 0.209 \\
& $60-75$ & 5 & 5 & 3 & 1 & & & & & & 0.596 \\
& More than 75 & 9 & 8 & 7 & 5 & 1 & & & & & \\
& & & & & $\mathrm{CR}=0.059$ & & & & \\
\hline Aspect & & & & & & & & & & & \\
& Flat & 1 & & & & & & & & & 0.023 \\
& North & 2 & 1 & & & & & & & & 0.047 \\
& Northeast & 7 & 4 & 1 & & & & & & & 0.204 \\
& East & 4 & 2 & 0.33 & 1 & & & & & & 0.082 \\
& South East & 9 & 8 & 3 & 4 & 1 & & & & & 0.362 \\
& South & 5 & 3 & 0.5 & 2 & 0.25 & 1 & & & & 0.125 \\
& South West & 4 & 2 & 0.25 & 1 & 0.2 & 0.5 & 1 & & & 0.078 \\
& West & 3 & 0.5 & 0.25 & 0.5 & 0.14 & 0.33 & 0.5 & 1 & & 0.046 \\
& North West & 2 & 1 & 0.14 & 0.33 & 0.12 & 0.25 & 0.33 & 0.5 & 1 & 0.033 \\
& & & & & CR $=0.025$ & & & & \\
\hline
\end{tabular}


Table 4. Cont.

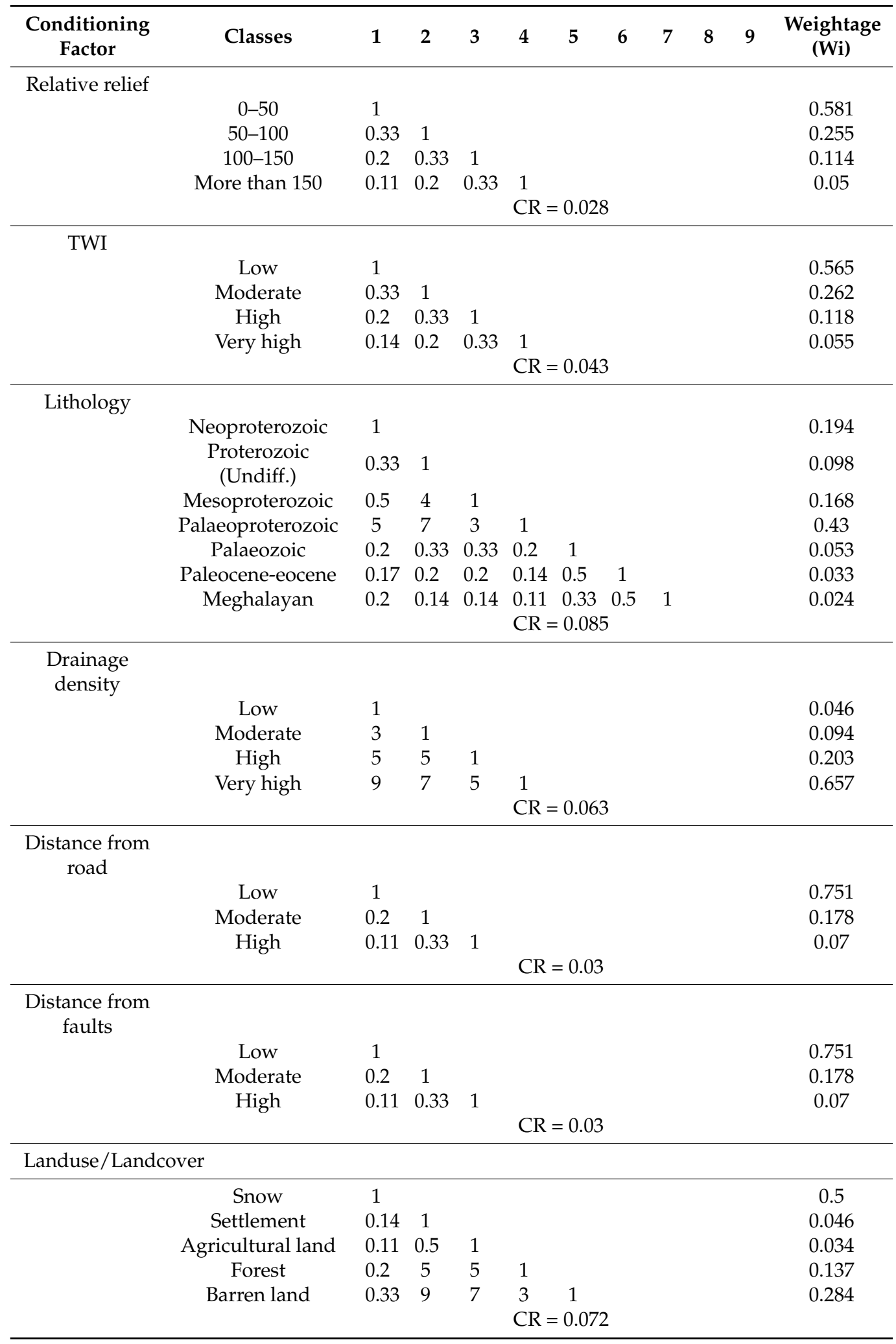

\section{Results and Discussion}

\subsection{Frequency Ratio}

The frequency ratio (FR) of the causative sub-factors is shown in the Table 2. The relative importance of the sub-factors can be evaluated from the weightage calculated in the Table 2. The impact of slopes less than $45^{\circ}$ is very low, but as the slope increases above $45^{\circ}$, 
the frequency ratio increases sharply. More than 39\% of landslides occur in regions where the slope is more than $75^{\circ}$, while such slopes only cover $18 \%$ of the study area. Higher slope values trigger the effect of gravity and also increase shear stress. The maximum frequency ratio (FR) value for slopes is 2.163. East, south-east, south, and North Slope aspects affect the occurrence of landslides more compared other directions. The frequency ratio (FR) is highest for the east direction (1.673), followed by the south east direction (1.486). These aspects receive more rainfall and are also subjected to erosion, which makes them more prone to landslides. The areas of low $(0-50 \mathrm{~m})$ and high $(100-150 \mathrm{~m})$ relative relief were more prone to landslides. The frequency ratio value for relative relief was highest (1.262) for $0-50 \mathrm{~m}$ relief, followed by 1.073 for 100-150 m relief. Lower values of topographic wetness index (TWI) have a significant effect on landslide occurrence, with a frequency ratio of 1.043 , while very high values of TWI $(\mathrm{FR}=0.037)$ had minimal effect on landslide occurrence. As TWI increases, FR decreases. Neoproterozoic age deposits had the highest FR values (1.252), followed by Mesoproterozoic deposits (FR = 1.653). The frequency ratios follow an increasing trend as the drainage density increases. For very high drainage density, the FR value was 1.685. Smaller distance from roads had a significant effect on the occurrence of landslides. Small distances from roads have the highest FR value i.e., 1.253, and similarly, smaller distances from faults also showed maximum FR (0.994) values in its category. Cutting activities performed during road construction reduced strength at the toe of slopes, making them more prone to landslides. Snow covered land $(\mathrm{FR}=2.059)$ was more prone to landslides, while agricultural land $(F R=0.562)$ had the least effect on landslide occurrence. After snow cover, barren land due to less vegetative cover was found to be more prone to landslides, with an FR value of 1.420.

The landslide susceptibility index (LSI) for the frequency ratio model varied from 3.173 to 13.297. The landslide susceptibility map is shown in Figure 5. The map is divided using natural breaks in ArcGIS showing very low, low, moderate, high and very high susceptibility zones. It is observed that high and very high landslide susceptibility zones cover around $45 \%$ of the study area, but more than $70 \%$ landslides occur in these regions. The very high susceptibility zone covers only $16.62 \%$ of the total study area but it is subjected to $40.7 \%$ of the total landslide area. $11 \%$ of the total landslide area occur in very low and low susceptibility zones while these zones cover more than $25 \%$ area.

\subsection{Shannon's Entropy Model}

The weightage of sub-factors in Shannon's entropy model was based on frequency ratio (FR) values. The weightage of causative factors was evaluated from FR values of sub-factors. It is found that distance from faults and distance from roads are the major causative factors which have a very high impact on the occurrence of landslides. The weightage of distance from faults is 0.159 and weightage of vicinity to roads is found to be 0.148 . The anthropogenic activities of road cutting and development have significantly increased landslide activities in the study area. The topographic wetness index (TWI) is also an important factor, with a weightage of 0.135 as per Shannon's entropy model. Slope has a weightage of 0.120 . Lithology, drainage density, and relative relief have almost equal weightage. 


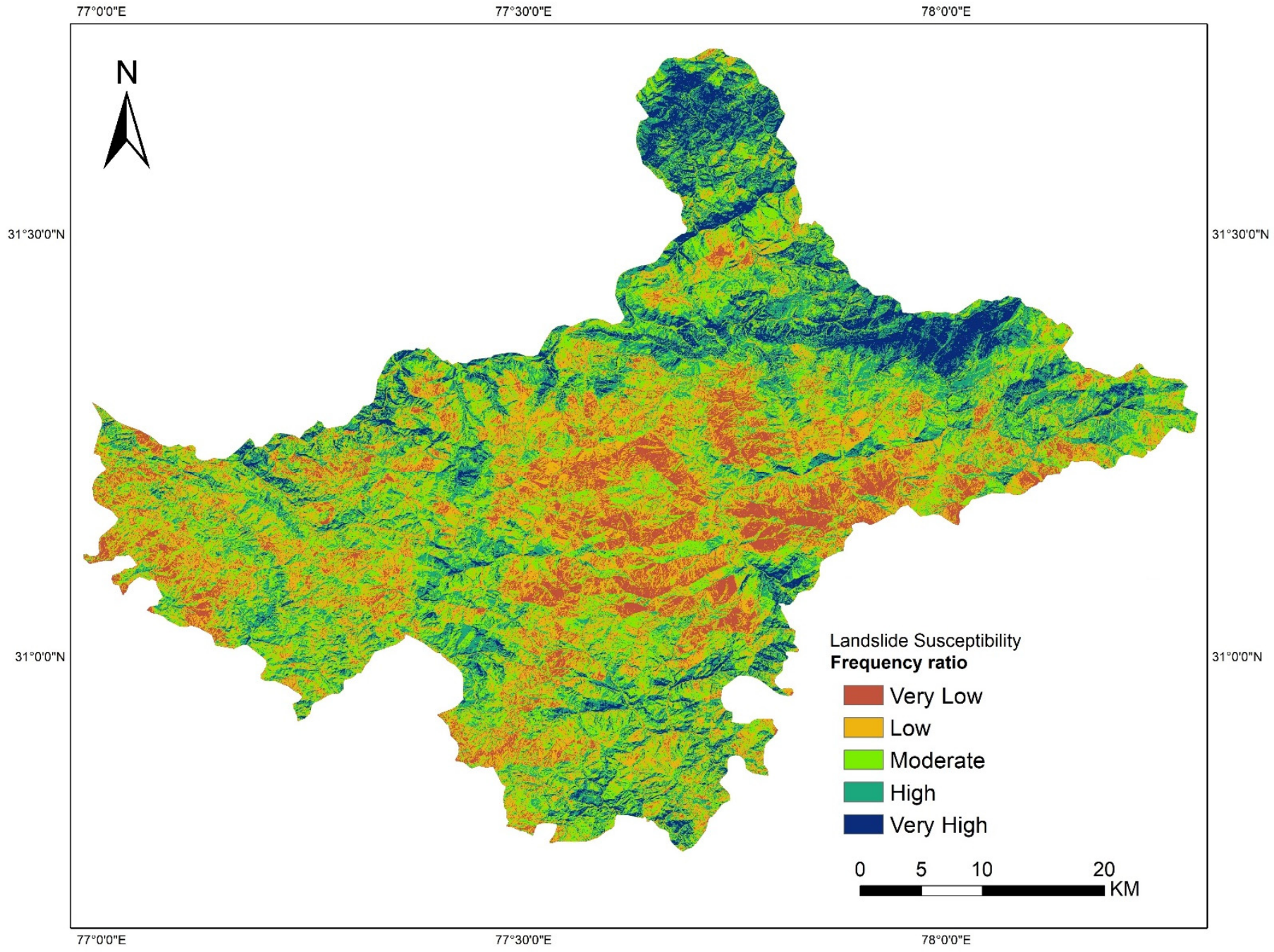

Figure 5. Landslide Susceptibility Map using Frequency Ratio.

The results of the FR model have been changed a little following the implementation of Shannon's entropy weightage to major causative factors. The simplest landslide susceptibility equation for this model is given as follows:

$$
\begin{aligned}
& \text { Landslide Susceptibility Index }(\text { LSI }) \\
& \qquad \begin{array}{l}
\quad 0.120 \times \text { Slope }+0.033 \times \text { Aspect } \\
+0.110 \times \text { Relative Relie }+0.135 \times \text { TWI } \\
\quad+0.109 \times \text { Lithology }+0.109 \times \text { Draiage Density } \\
+0.148 \times \text { Distance from Roads } \\
+0.159 \times \text { Distance from Faults }+0.078 \times \text { Land use }
\end{array}
\end{aligned}
$$

LSI varies from 0.402 to 1.412 for Shannon's entropy model. The final landslide susceptibility map is divided into five categories, i.e., very low, low, moderate, high and very high, using natural breaks. The landslide susceptibility map by Shannon's entropy is shown in the Figure 6. Shannon's entropy model shows that $12.06 \%$ of the area has very high susceptibility, which contains $31.93 \%$ landslide area of the region. The model shows that $23.66 \%$ of the area has high susceptibility, which contains $34.45 \%$ landslide area. Very low and low landslide susceptibility zones cover $9.84 \%$ and $24.85 \%$ of study area, respectively. 


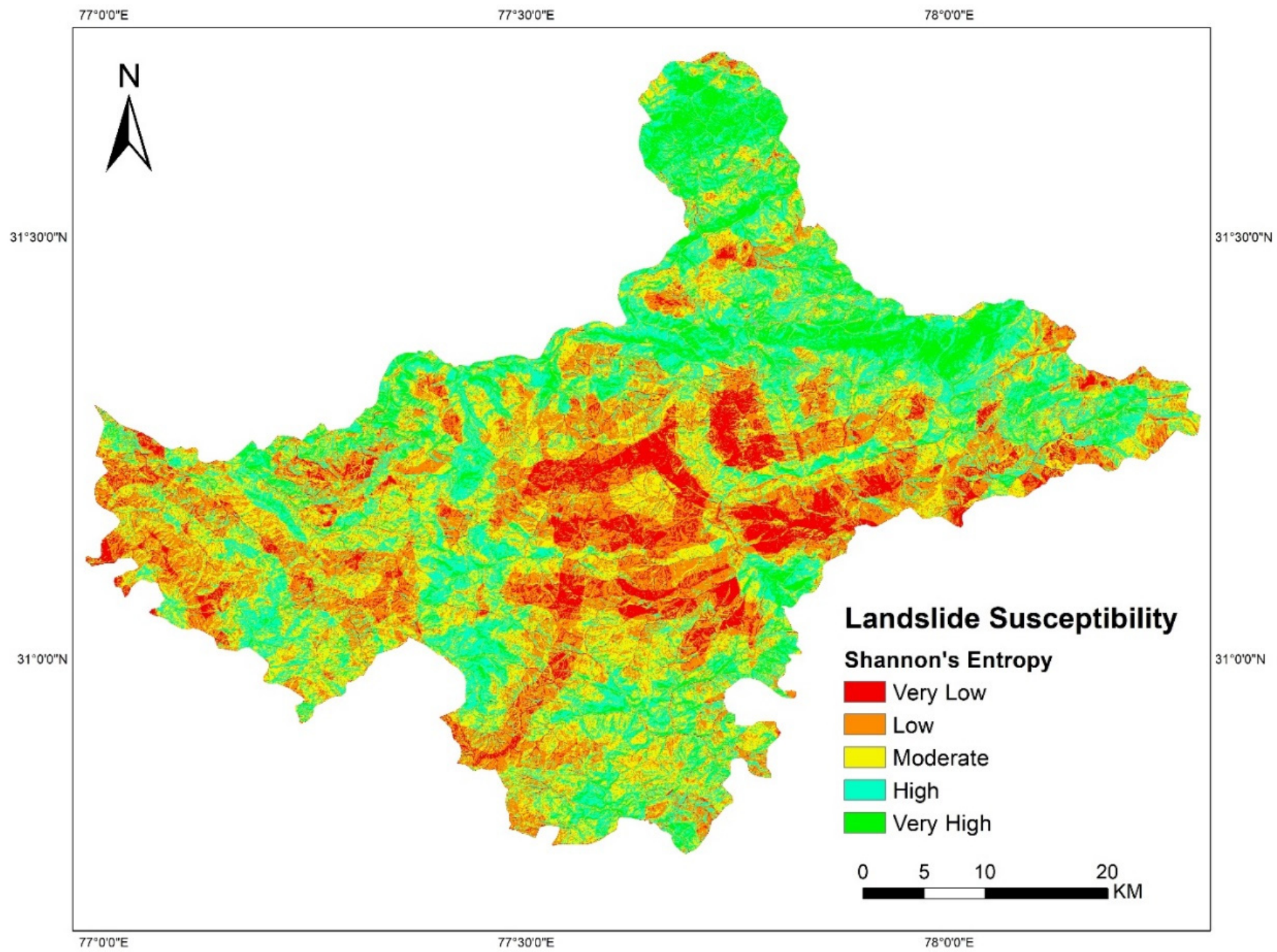

Figure 6. Landslide susceptibility map using Shannon's entropy.

\subsection{Analytic Hierarchy Process (AHP) Approach}

According to the AHP model, distance from roads and drainage density are the major factors which have high weightage, i.e., 0.280 and 0.205 respectively. Higher weightage of distance from roads shows the significance of anthropogenic activities towards occurrence of landslides. Lithology has a weightage of 0.096 in the AHP model. Neoproterozoic and mesoproterozoic deposits have been more responsible for occurrence of landslides compared to other lithological units, as per the AHP model. Distance from faults has a weightage of 0.161 , which states the high significance of this factor in the occurrence of landslides, while aspect has the lowest weightage, i.e., 0.016. Slope (weightage $=0.105$ ) and (weightage $=0.081$ ) are important DEM-based factors which affect the landslide phenomenon. Lower TWI values are more responsible for the occurrence of landslides compared to higher values. Tables 3 and 4 show the AHP weightage for all the factors and sub-factors, respectively.

The landslide susceptibility index (LSI) for the AHP approach is given by following equation:

$$
\begin{aligned}
& \text { Landslide Susceptibility Index }(\text { LSI }) \\
& \qquad \begin{aligned}
& 0.105 \times \text { Slope }+0.016 \times \text { Aspect } \\
& +0.036 \times \text { Relative Relief }+0.081 \times \text { TWI } \\
& +0.096 \times \text { Lithology }+0.205 \times \text { Draiage Density } \\
& +0.280 \times \text { Distance from Roads } \\
& +0.168 \times \text { Distance from Faults }+0.020 \times \text { Land use }
\end{aligned}
\end{aligned}
$$


The landslide susceptibility index (LSI) for the landslide susceptibility map obtained from the AHP approach varies from 0.061 to 0.648 . The landslide susceptibility map is divided by natural breaks based on the landslide susceptibility index shown in Figure 7 .

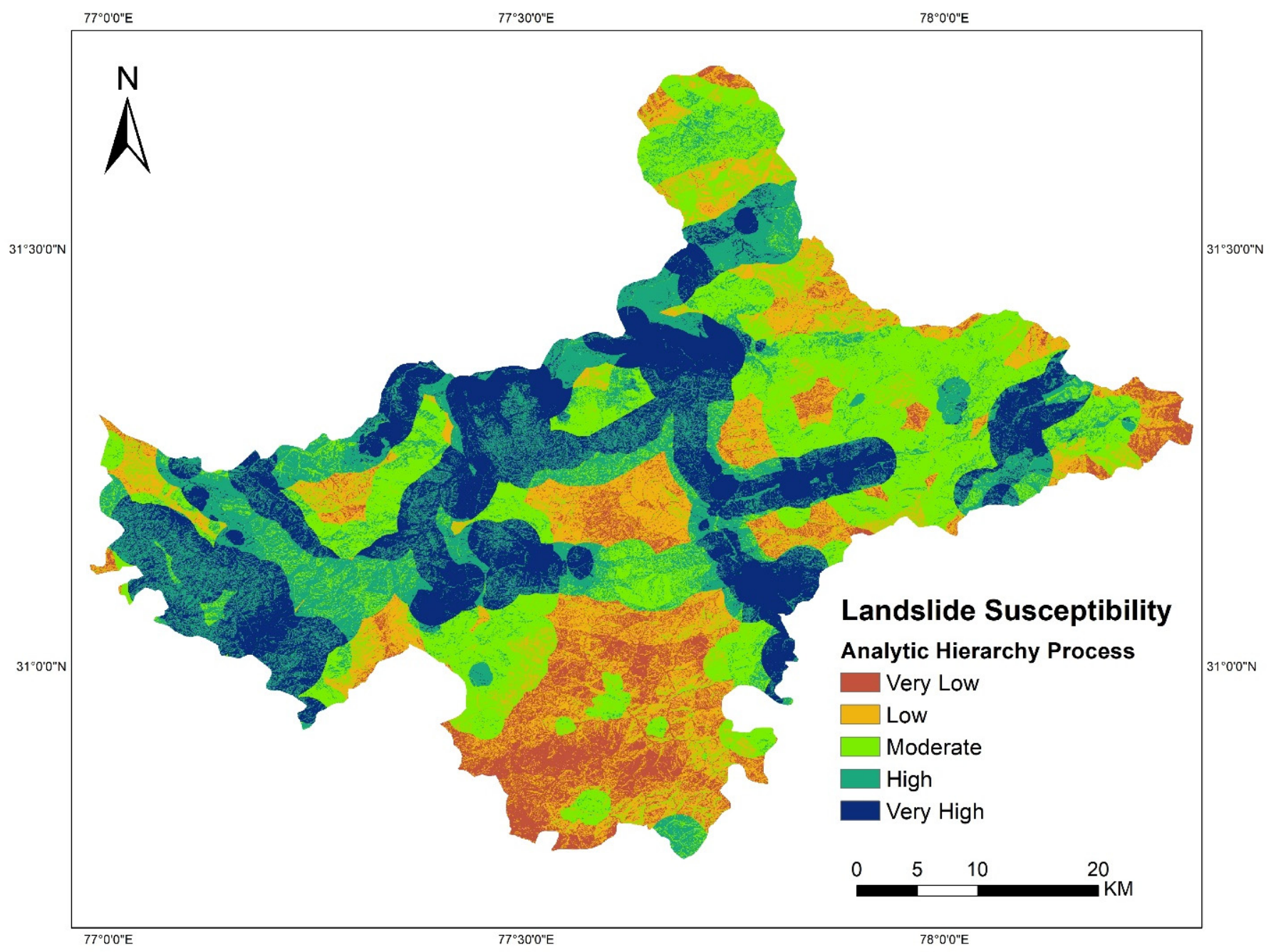

Figure 7. Landslide susceptibility map using analytic hierarchy process.

It is found that $23.05 \%$ area lies under very low landslide susceptibility according to the AHP approach, and contains around $10 \%$ landslide area. Around $24 \%$ area lies under high susceptibility and contains around 29\% landslide area, while around $8 \%$ area lies under very high susceptibility containing $9.24 \%$ of the landslides. It seems evident that the AHP model remains less efficient in the classification of landslide susceptibility as compared to the previous two models. The relative importance of the causative factors has been selected based on the subjective approach of experts. There is no mathematical relationship for the comparison of the relative importance of causative factors and subfactors. In qualitative techniques such as AHP, the input can be varied for better output. The lower accuracy in the AHP may be due to underestimation and overestimation of the impacts of some causative factors and sub-factors.

\subsection{Validation of Results}

The results were validated using a receiver operating curve (ROC). Figure 8 shows the ROCs for the landslide susceptibility maps prepared with different techniques. The ROC curves show a relationship between sensitivity and (1-specificity). The area under curve (AUC) value for the frequency ratio model is 0.925 , which shows very high accuracy. The frequency ratio model shows very encouraging results in the study area. Shannon's 
entropy model shows an accuracy of 0.883 . The analytic hierarchy process (AHP) based landslide susceptibility map shows an AUC value of 0.732, which is the lowest among all the models.

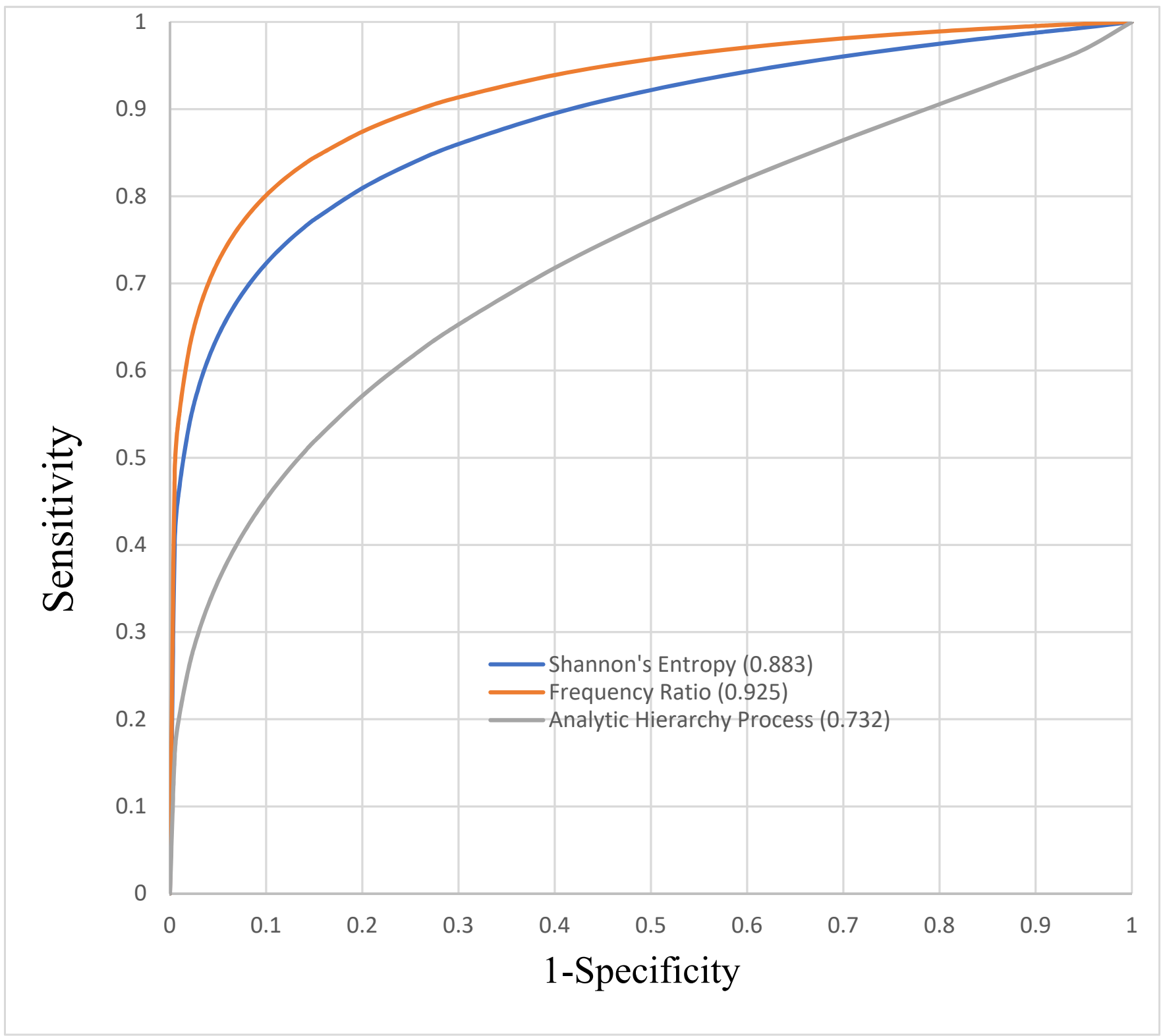

Figure 8. Receiver operating characteristic curve for validation.

\section{Conclusions and Future Scope}

Landslides are one of the most disastrous phenomena in the Himalayan region. In this study, statistical approaches and expert based approaches are compared for landslide susceptibility mapping in a GIS environment. The frequency ratio (FR) model shows better accuracy i.e., 0.925 compared to Shannon's entropy model and the AHP. Shannon's entropy model had an accuracy of 0.883 , and AHP model had an accuracy of 0.732 using the ROC technique. The FR model and Shannon's entropy model have inputs based on landslide inventories which cannot be varied, while in the AHP model, the input can be varied to improve accuracy. The relative importance of each factor and sub-factor can be observed from these models. It can be concluded that frequency ratio is the most efficient method, and is the simplest to implement in quantitative methods. An accurate and extensive 
landslide inventory is required for the efficient implementation of frequency ratio models. The results from qualitative methods like AHP depend upon the selection of weights, so need additional research. AHP can be used in the regions for which historical landslide data is not available. There is evidence of rock fall, debris flows and landslides in high and very high susceptibility zones. Landslide susceptibility maps using these models have not previously been prepared in this study area. Therefore, the results of this study can provide a very useful input for the planner and risk managers.

The study could be extended to predict landslide hazard and risk assessment of the study area. The seasonal variation in causative factors such as rainfall, land-use variation and vegetation cover variation can be studied and their impact on the occurrence of landslides can be observed.

Author Contributions: Conceptualization: Sandeep Panchal, Amit K. Shrivastava, Formal Analysis: Sandeep Panchal, Investigation: Sandeep Panchal; Resources: Sandeep Panchal, Amit K. Shrivastava; Data Curation; Sandeep Panchal, Amit K. Shrivastava; Writing-Original Draft Preparation: Sandeep Panchal; Writing-Review and Editing: Sandeep Panchal, Amit K. Shrivastava; Figure editing: Sandeep Panchal; Supervision; Amit K. Shrivastava. Both authors have read and agreed to the published version of the manuscript.

Funding: No funding is obtained for this work.

Data Availability Statement: Not applicable.

Conflicts of Interest: The authors declare no conflict of interest.

\section{References}

1. Aleotti, P.; Chowdhury, R. Landslide hazard assessment: Summary review and new perspectives. Bull. Int. Assoc. Eng. Geol. 1999, 58, 21-44. [CrossRef]

2. Lee, S. Application and verification of fuzzy algebraic operators to landslide susceptibility mapping. Environ. Earth Sci. 2006, 52, 615-623. [CrossRef]

3. Xu, C.; Xu, X.; Yu, G. Landslides triggered by slipping-fault-generated earthquake on a plateau: An example of the 14 April 2010 , Ms 7.1, Yushu, China earthquake. Landslides 2012, 10, 421-431. [CrossRef]

4. Mersha, T.; Meten, M. GIS-based landslide susceptibility mapping and assessment using bivariate statistical methods in Simada area, northwestern Ethiopia. Geoenviron. Disasters 2020, 7, 20. [CrossRef]

5. Khan, H.; Shafique, M.; Khan, M.A.; Bacha, M.A.; Shah, S.U.; Calligaris, C. Landslide susceptibility assessment using Frequency Ratio, a case study of northern Pakistan. Egypt. J. Remote Sens. Space Sci. 2018, 22, 11-24. [CrossRef]

6. Meten, M.; Bhandary, N.P.; Yatabe, R. GIS-based frequency ratio and logistic regression modelling for landslide susceptibility mapping of Debre Sina area in central Ethiopia. J. Mt. Sci. 2015, 12, 1355-1372. [CrossRef]

7. Van Westen, C.J.; Rengers, N.; Soeters, R. Use of Geomorphological Information in Indirect Landslide Susceptibility Assessment. Nat. Hazards 2003, 30, 399-419. [CrossRef]

8. Prasad, A.S.; Pandey, B.W.; Leimgruber, W.; Kunwar, R.M. Mountain hazard susceptibility and livelihood security in the upper catchment area of the river Beas, Kullu Valley, Himachal Pradesh, India. Geoenviron. Disasters 2016, 3, 1. [CrossRef]

9. Gokceoglu, C.; Aksoy, H. Landslide susceptibility mapping of the slopes in the residual soils of the Mengen region (Turkey) by deterministic stability analyses and image processing techniques. Eng. Geol. 1996, 44, 147-161. [CrossRef]

10. Lee, S.; Ryu, J.-H.; Won, J.-S.; Park, H.-J. Determination and application of the weights for landslide susceptibility mapping using an artificial neural network. Eng. Geol. 2003, 71, 289-302. [CrossRef]

11. Yeon, Y.-K.; Han, J.-G.; Ryu, K.H. Landslide susceptibility mapping in Injae, Korea, using a decision tree. Eng. Geol. 2010, 116, 274-283. [CrossRef]

12. Pourghasemi, H.R.; Mohammady, M.; Pradhan, B. Landslide susceptibility mapping using index of entropy and conditional probability models in GIS: Safarood Basin, Iran. Catena 2012, 97, 71-84. [CrossRef]

13. Singh, K.; Kumar, V. Hazard assessment of landslide disaster using information value method and analytical hierarchy process in highly tectonic Chamba region in bosom of Himalaya. J. Mt. Sci. 2018, 15, 808-824. [CrossRef]

14. Gautam, P.; Kubota, T.; Sapkota, L.M.; Shinohara, Y. Landslide susceptibility mapping with GIS in high mountain area of Nepal: A comparison of four methods. Environ. Earth Sci. 2021, 80, 359. [CrossRef]

15. Hasekiogulları, G.D.; Ercanoglu, M. A new approach to use AHP in landslide susceptibility mapping: A case study at Yenice (Karabuk, NW Turkey). Nat. Hazards 2012, 63, 1157-1179. [CrossRef] 
16. Kayastha, P.; Dhital, M.; De Smedt, F. Application of the analytical hierarchy process (AHP) for landslide susceptibility mapping: A case study from the Tinau watershed, west Nepal. Comput. Geosci. 2013, 52, 398-408. [CrossRef]

17. El Jazouli, A.; Barakat, A.; Khellouk, R. GIS-multicriteria evaluation using AHP for landslide susceptibility mapping in Oum Er Rbia high basin (Morocco). Geoenviron. Disasters 2019, 6, 3. [CrossRef]

18. Sujatha, E.R.; Sridhar, V. Mapping debris flow susceptibility using analytical network process in Kodaikkanal Hills, Tamil Nadu (India). J. Earth Syst. Sci. 2017, 126, 116. [CrossRef]

19. Shahabi, H.; Ahmad, B.B.; Khezri, S. Evaluation and comparison of bivariate and multivariate statistical methods for landslide susceptibility mapping (case study: Zab basin). Arab. J. Geosci. 2012, 6, 3885-3907. [CrossRef]

20. Kavzoglu, T.; Sahin, E.K.; Colkesen, I. An assessment of multivariate and bivariate approaches in landslide susceptibility mapping: A case study of Duzkoy district. Nat. Hazards 2014, 76, 471-496. [CrossRef]

21. Ram, P.; Gupta, V.; Devi, M.; Vishwakarma, N. Landslide susceptibility mapping using bivariate statistical method for the hilly township of Mussoorie and its surrounding areas, Uttarakhand Himalaya. J. Earth Syst. Sci. 2020, 129, 167. [CrossRef]

22. Pradhan, B. Landslide susceptibility mapping of a catchment area using frequency ratio, fuzzy logic and multivariate logistic regression approaches. J. Indian Soc. Remote Sens. 2010, 38, 301-320. [CrossRef]

23. Sarkar, S.; Roy, A.; Martha, T.R. Landslide susceptibility assessment using Information Value Method in parts of the Darjeeling Himalayas. J. Geol. Soc. India 2013, 82, 351-362. [CrossRef]

24. Akgun, A.; Erkan, O. Landslide susceptibility mapping by geographical information system-based multivariate statistical and deterministic models: In an artificial reservoir area at Northern Turkey. Arab. J. Geosci. 2016, 9, 165. [CrossRef]

25. Pradhan, B.; Oh, H.-J.; Buchroithner, M. Weights-of-evidence model applied to landslide susceptibility mapping in a tropical hilly area. Geomat. Nat. Hazards Risk 2010, 1, 199-223. [CrossRef]

26. Polykretis, C.; Chalkias, C. Comparison and evaluation of landslide susceptibility maps obtained from weight of evidence, logistic regression, and artificial neural network models. Nat. Hazards 2018, 93, 249-274. [CrossRef]

27. Shano, L.; Raghuvanshi, T.K.; Meten, M. Landslide susceptibility evaluation and hazard zonation techniques-A review. Geoenviron. Disasters 2020, 7, 1-19. [CrossRef]

28. Mathews, R.P. Ground Information Water Booklet Shimla District, Himachal Pradesh, Ministry of Water Resources, Central Ground Water Board, Government of India. 2013. Available online: http://cgwb.gov.in/District_Profile/HP/Shimla.pdf (accessed on 1 April 2021).

29. District Survey Document Shimla. Available online: https://emerginghimachal.hp.gov.in/miningstone/survay_docs/shimla.pdf (accessed on 3 May 2021).

30. Guzzetti, F.; Mondini, A.C.; Cardinali, M.; Fiorucci, F.; Santangelo, M.; Chang, K.-T. Landslide inventory maps: New tools for an old problem. Earth Sci. Rev. 2012, 112, 42-66. [CrossRef]

31. Regmi, A.D.; Yoshida, K.; Pourghasemi, H.R.; DhitaL, M.R.; Pradhan, B. Landslide susceptibility mapping along BhalubangShiwapur area of mid-Western Nepal using frequency ratio and conditional probability models. J. Mt. Sci. 2014, 11, 1266-1285 [CrossRef]

32. Saleem, N.; Huq, E.; Twumasi, N.Y.D.; Javed, A.; Sajjad, A. Parameters Derived from and/or Used with Digital Elevation Models (DEMs) for Landslide Susceptibility Mapping and Landslide Risk Assessment: A Review. ISPRS Int. J. Geo-Inf. 2019, 8, 545. [CrossRef]

33. Bahrami, S.; Rahimzadeh, B.; Khaleghi, S. Analyzing the effects of tectonic and lithology on the occurrence of landslide along Zagros ophiolitic suture: A case study of Sarv-Abad, Kurdistan, Iran. Bull. Int. Assoc. Eng. Geol. 2019, 79, 1619-1637. [CrossRef]

34. Nebeokike, U.C.; Igwe, O.; Egbueri, J.C.; Ifediegwu, S.I. Erodibility characteristics and slope stability analysis of geological units prone to erosion in Udi area, southeast Nigeria. Model. Earth Syst. Environ. 2020, 6, 1061-1074. [CrossRef]

35. Nepal, N.; Chen, J.; Chen, H.; Wang, X.; Sharma, T.P.P. Assessment of landslide susceptibility along the Araniko Highway in Poiqu/Bhote Koshi/Sun Koshi Watershed, Nepal Himalaya. Prog. Disaster Sci. 2019, 3, 100037. [CrossRef]

36. Sen, S.; Mitra, S.; Debbarma, C.; De, S.K. Impact of faults on landslide in the Atharamura Hill (along the NH 44), Tripura. Environ. Earth Sci. 2014, 73, 5289-5298. [CrossRef]

37. Yang, L.; Liu, E. Numerical Analysis of the Effects of Crack Characteristics on the Stress and Deformation of Unsaturated Soil Slopes. Water 2020, 12, 194. [CrossRef]

38. Demir, G.; Aytekin, M.; Akgun, A. Landslide susceptibility mapping by frequency ratio and logistic regression methods: An example from Niksar-Resadiye (Tokat, Turkey). Arab. J. Geosci. 2014, 8, 1801-1812. [CrossRef]

39. Park, S.; Choi, C.; Kim, B.; Kim, J. Landslide susceptibility mapping using frequency ratio, analytic hierarchy process, logistic regression, and artificial neural network methods at the Inje area, Korea. Environ. Earth Sci. 2012, 68, 1443-1464. [CrossRef]

40. Silalahi, F.E.S.; Arifianti, Y.; Hidayat, F. Landslide susceptibility assessment using frequency ratio model in Bogor, West Java, Indonesia. Geosci. Lett. 2019, 6, 10. [CrossRef]

41. Roodposhti, M.S.; Aryal, J.; Shahabi, H.; Safarrad, T. Fuzzy Shannon Entropy: A Hybrid GIS-Based Landslide Susceptibility Mapping Method. Entropy 2016, 18, 343. [CrossRef]

42. Sharma, L.P.; Patel, N.; Ghose, M.K.; Debnath, P. Development and application of Shannon's entropy integrated information value model for landslide susceptibility assessment and zonation in Sikkim Himalayas in India. Nat. Hazards 2014, 75, 1555-1576. [CrossRef] 
43. Saaty, R.W. The analytic hierarchy process-what it is and how it is used. Math. Model. 1987, 9, 161-176. [CrossRef]

44. Zhu, L.; Huang, J.-F. GIS-based logistic regression method for landslide susceptibility mapping in regional scale. J. Zhejiang Univ. A 2006, 7, 2007-2017. [CrossRef]

45. Map of India. Available online: https:/ /d-maps.com/ (accessed on 2 January 2021). 